\title{
"We swam before we breathed or walked' : able-bodied belonging in popular stories of evolutionary biology
}

\section{Vaahtera, Touko}

2016

Vaahtera , T 2016 , ' "We swam before we breathed or walked' : able-bodied belonging in popular stories of evolutionary biology ' , Disability \& Society , vol. 31 , no. 5 , pp. 591-603 . https://doi.org/10.1080/0

http://hdl.handle.net/10138/229611

https://doi.org/10.1080/09687599.2016.1188767

other

acceptedVersion

Downloaded from Helda, University of Helsinki institutional repository.

This is an electronic reprint of the original article.

This reprint may differ from the original in pagination and typographic detail.

Please cite the original version. 
Published as: Vaahtera, Touko. 'We swam before we breathed or walked': Able-bodied Belonging in Popular Stories of Evolutionary Biology. Disability \& Society. Vol. 31, issue 5 (2016).

\section{'We swam before we breathed or walked': Able-bodied Belonging in Popular Stories of Evolutionary Biology}

As Sharon Snyder and David Mitchell (2006) have shown, disability has appeared in evolutionary accounts since the days of Charles Darwin. According to them, scientific accounts have made disabled people appear as 'throwbacks,' or objects that can help nondisabled people acquire knowledge about themselves (ibid.). With this history in mind, I turn here to the present, and to evolutionary biological accounts that emphasize the similarities between human and non-human species. What possibilities does this emphasis offer for questioning ableist assumptions of bodies, and what cultural mechanisms prevent evolutionary biology from emerging in a way that would question the idea of the speciestypical body of a human being?

While evolutionary biological accounts challenge the position of humans as central, and the way that particular abilities appear as self-evidently useful, the idea of evolution enables humans to feel that they belong to the animal world. It is this feeling of belonging to the animal world that I turn to. I wish to explore how the cultural understandings that invoke the feeling of belonging rely on bodies that have been saturated with particular meanings. In order to focus on this mechanism, I put forward the formulation of 'able-bodied belonging.' In particular, the present paper explores how ableism and speciesism operate in evolutionary 
biological accounts. In this respect, my investigation develops the recent conversations about the relationship between ableism and speciesism (Vehmas 1999, Groce \& Marks 2000, Taylor 2012).

In what follows, I explore four cultural items, all exemplifying popular culture in the broad sense: a 1979 editorial article from the New York Times, a BBC documentary entitled 'The Family that Walks on All Fours' and YouTube discussions about it, Neil Shubin's book Your Inner Fish - The amazing discovery of our 375-million-year-old ancestor, and finally a book which draws on Shubin's work, Lynn Sherr's Swim - Why we love the water. What is particularly specific to these four cultural texts is that they popularize the ideas of evolutionary biology.

The paper spotlights Tiktaalik, a fossilized animal that Neil Shubin dug up with other paleontologists in 2004. Tiktaalik has been understood to be a significant species in the history of evolution because it was a fish that was able to come up onto land. In 2008 The Telegraph stated that Shubin's book Your Inner Fish 'would be Darwin's book of the year if he were around today (Katsoulis 2008).' Indeed, many scientists already in the nineteenth century committed popular versions of their work to paper, and in this way acquired a larger readership (Castañeda 2001). It is important to keep in mind that popular science has a long history (Castañeda 2001, Oikkonen 2013, 2015). Furthermore, Shubin’s popular scientific work should not be seen as less scientific but instead as fundamentally part of scientific writing.

The methodological approach of the article draws on cultural studies and feminist science studies (Hall 2012, Haraway 1997, Martin 1994, Oikkonen 2013, Snyder \& Mitchell 2006). I investigate how ableism, speciesism and racism operate in the cultural products that put 
forward evolutionary biological accounts. In this investigation, I will explore the cultural mechanisms that enable 'our' belonging to the animal world and simultaneously exclude particular bodies from humanity. Donna Haraway $(1997,269)$ reminds that even though scientific knowledges often appear as having nothing to do with culture, science actually is a 'culture of no culture.' In this respect, I emphasize how evolutionary biological accounts emerge from various cultural sites - and also from beyond the sphere that is associated with science. Moreover, as Haraway $(1989,14)$ has pointed out the ideas put forward in natural sciences publications can be used for various ends by people who are not scientists themselves. Scientific ideas can be used in making sense of specific cultural practices that have not originally been the objects of particular scientific explorations. This does not mean that this kind of circulation of scientific ideas would ruin 'real' science. Rather, it implies that scientists cannot control how ideas that are associated with the realm of science function. In this article, I trace how Shubin's ideas travel to another context and how they frame the larger cultural imaginary of human beings who are connected to non-human species.

When exploring the feeling of belonging to the animal world through reading popular versions of evolutionary biology, I investigate how, in the cultural imaginaries, swimming has illustrated the idea that humans are connected to non-human species. As the title 'We swam before we breathed or walked' implies, it is not unusual to associate swimming with the idea that humans are connected to non-human species, as 'we,' too, came from the water. Hence, swimming can appear as something natural because it reminds 'us' from 'our' past, and yet it is something that needs to be learned. This leads to a paradox: swimming appears to be an exceptional ability that is possible to achieve through training but which appears to precede 'walking' and even 'breathing.' I view this paradox as a fruitful opportunity to unpack ableist assumptions about species and abilities. 


\section{Able-bodied belonging to the animal world}

Fiona Kumari Campbell $(2001,44)$ defines the term 'ableism' in the following way: 'A network of beliefs, processes and practices that produce a particular kind of self and body (the corporeal standard) that is projected as the perfect, species-typical and therefore essential and fully human.' Campbell's definition of ableism emphasizes that particular cultural stories make it possible for able-bodiedness to appear as a marker of true humanity. Compulsory able-bodiedness, as Robert McRuer $(2006,1)$ states, assumes able-bodiedness to be the 'natural order of things.' Moreover, drawing on Michael Warner (2000), McRuer's idea of compulsory able-bodiedness highlights how normalcy is tempting in many ways. 'Being one of the rest of us' appears to be something many people want (Warner 2000, 53, McRuer 2006, 7). But what does 'being one of the rest of us' mean in the context of evolutionary biology? Venla Oikkonen (2015) has recently pointed out that the cultural understandings with regards to genetics enable forms of belonging beyond the borders of the nation state. According to Oikkonen $(2015,766)$ the notion of genetic kinship understands all human beings as 'a global human family.' Even though the cultural texts put forward this form of belonging, one that appears to include all human beings, she explains how the texts assume the subject who belongs to 'the global human family' to be a white, heterosexual European. Whereas Oikkonen (2015) has investigated how genetics enables particular human beings to feel that they are members of the 'global human family,' my article explores the kind of belonging that emerges from the present ideas of evolutionary biology.

The formulation of 'able-bodied belonging' aims to make possible the exploration of particular affective ties where ableism frames the cultural politics that invoke forms of belonging. The present paper explores how the cultural stories about belonging to the animal world invoke emotions in a way that rests on ableist assumptions. To do so, I draw on Sara 
Ahmed's (2004) idea of the 'cultural politics of emotion.' That is to say, Ahmed (2004) points to the political and cultural underpinnings of emotions: particular bodies do not invoke particular affects just accidentally, but because these bodies - or rather bodies that resemble them - have been used over and over again in powerful cultural stories where particular affects have been connected with these bodies. Further, belonging - even when it appears as something natural - has been engendered through exclusions, as Nira Yuval-Davis (2011) theorizes. Although for Yuval-Davis (2011) 'the politics of belonging' concerns manifold modes of belonging with respect to citizenship, this article explores how belonging figures in evolutionary biological accounts. I turn to the theme of belonging to the animal world, because cultural stories about animals and abilities do matter (cf. Hemmings 2011). They depict the kinds of bodies that should be valued, and the forms of belonging that should be maintained.

\section{'We are a quadruped again'}

An anonymous writer in the New York Times (Aug 1,1979) once reflected on how swimming makes one realize how one is part of the animal world: "Swimming in a summer pond, we notice how natural it is to use all four limbs to travel along. We are a quadruped again; even a stroke is called 'the crawl'." Here, swimming makes one realize that one is 'a quadruped again.' It seems that the use of 'all fours' connects people to their own past, which appears to be something 'natural.' The writer assumes that it is 'natural $[\ldots]$ to use all four limbs.' Nonhuman animals, who use four limbs in locomotion, illuminate this past which is 'natural.' In this section, I consider this New York Times article together with a BBC documentary that focuses on human quadrupedalism. The documentary was released almost thirty years after the article. However, both cultural texts associate quadrupedalism with the past even though 
in both texts human quadrupedalism concerns the present. Reading these two very different cultural texts together, I tease out the following question: How can quadrupedalism be connected with the past through the existing human bodies that quadruped?

Feminists studying scientific practices have pointed out that animals are often used as 'mirrors,' and that animal behavior appears to indicate what is natural for people (Haraway 1989, Terry 2000). Haraway $(1989,64)$ puts it this way: 'Nature is given our history, even as our history is made to seem natural because we see ourselves in these animate, multiform mirrors.' The writer of the New York Times article reflects on the experience of swimming, with the help of animals. However, it is not a concrete animal in this particular situation that makes this realization possible: it is an animal in the stories of science that allows the writer to connect human locomotion with that of non-human quadrupeds. This animal, a quadruped, which ostensibly moves in a different way than people on dry land, reminds the writer that people, too, have this potential to use all fours when moving.

Regarding the notion that when human beings move with the help of four limbs this associates them with the animal world, I would like to emphasize the word 'crawl.' As the writer of the New York Times article states, "we are a quadruped again; even a stroke is called 'the crawl'." Even though the writer does not connect this term to disability, it is indeed the association between crawling and animals which connects some people with disabilities to animals. An adult human who crawls disrupts the boundaries of humanity and adulthood. In 2006, the BBC aired a documentary film entitled 'The Family that Walks on All Fours' (directed by Jemima Harrison). The documentary was uploaded to YouTube and has already been viewed almost two million times. When opening this YouTube feature, YouTube immediately indicates in the right-hand column of the web page where other, assumedly 
similar, material can be viewed. These uploadings consist of documentary films such as ' $\mathrm{My}$ face is eating me alive' (3, 302233 views), 'The girl who never ate' (2, 782408 views), and 'The twins who share a body' $(1,207683$ views). In this YouTube context, 'The Family that Walks on All Fours' is instantly associated with 'similar' kinds of sensational representations of disability. The documentary depicts how scientists investigated a Turkish family whose children, already adults at the time of the filming, walk 'on all fours.'

Even though the New York Times article seems to painlessly link one's corporeality to other animals when discussing swimming, the link between the human body and the animal world appears to call up very different associations when an adult uses all fours on dry land. In the article, to become 'a quadruped again' means that one can associate oneself with something that is natural. However, in 'The Family that Walks on All Fours,' quadrupedalism is associated with unnaturalness. Some YouTube commenters have questioned the authenticity of the documentary: 'Was this a real documentary? Are we sure it isn't a joke?' 'I bet you they just hired some family to be filmed walking around on all fours.' Actually, the YouTube commenters are not the only ones who are amazed here. The film begins by featuring a scholar from the University of Cambridge, Nicholas Humphrey. As he explains, he learned that Uner Tan, a Turkish neuroscientist, had recently written an intriguing paper on quadrupedalism, and goes on to say that the paper 'was about a family of quadrupeds, human beings walking like animals.' Humphrey, apparently excited, wanted to find out more about 'this remarkable family' and immediately went to Turkey.

It is almost impossible to take Humphrey's statements as anything other than dehumanizing. Drawing on disability theory and critical animal studies, Mel Chen (2012) explains that the processes of dehumanization require non-human forms of life and matter. According to Chen 
(2012), if a human being is connected with non-humans such as vegetables or non-human animals, the human being is degraded. In contrast, if a non-human being is associated with humans, this does not appear degrading. In the following sections we will see how a nonhuman animal is connected with human beings. Here, however, I emphasize that when a human being uses quadrupedalism in locomotion, this kind of human being needs to be located in the past. This reinforces the idea that existing human beings are not like animals. At the same time, when this maneuver reinforces the distinction between human and nonhuman animal, human beings who are associated with non-human animals become less human. This is how dehumanization works.

In the film's main sequences the family is introduced to the viewers, who are able to watch how some of its members move within and outside their house. Close-up shots allow viewers to concentrate on the body parts of these individuals, while the narrator states: 'This Turkish family is walking the way we did more than four million years ago.' The way in which the narrator locates 'us' as quadrupeds in the past, highlights that quadrupedalism cannot be a quality of existing human beings. Moreover, she makes it visibly evident that to her, walking on all fours is anomalous, stating that it 'feels very unnatural.' Ahmed (2004) emphasizes that such strong reactions are related to the history of cultural figures. In this sense, the way some bodies 'feel very unnatural' should not lead one to think that it actually says much about the object of this affective reaction (e.g. Ahmed 2004, Vaahtera \& Vähäpassi 2014). Rather, following Ahmed, such an affective reaction emerges since particular bodies have appeared in cultural stories where these bodies have been saturated with particular affects. 
While 'The Family that Walks on All Fours' focuses on sensationally presented human beings who use all fours, several sequences of the documentary make clear the ideas of human evolution. In this respect, the Turkish family illustrates evolutionary accounts and tells the story of how human beings developed into animals that walk on two legs. It is important to note that here, concrete existing bodies are helping viewers to understand human evolution. This manner is reminiscent of older scientific explorations into evolution that connected existing non-whites with non-human species and underdevelopment (e.g. Goulden 2009). The film echoes this historical association when it connects quadrupedalism with the bodies of people of color as well as underdevelopment. At the same time, development, bipedalism and whiteness are connected with each other.

As the film proceeds, scientists examine the family members in various ways and take some of them to a hospital for brain scans. One member struggles and screams when she is made to lie on an examination table. Three people who walk upright (two nurses and her father) restrain her so that the procedure can begin. Watching this scene is difficult. Humphrey later interprets the brain scan results with other scientists in Cambridge. They consider the possibility that perhaps difficulties in balance have caused the quadrupedalism. These 'unnatural' quadrupeds from Turkey are then contrasted with 'healthy' children from North America. The narrator points out that it is not unusual for a 'perfectly healthy American child' to sometimes use all fours when moving. However, Humphrey explains that in North America and England, children who use all fours after crawling receive physiotherapy. Given this, Humphrey goes on to suggest that the Turkish siblings' lack of physiotherapy partly explains their quadrupedalism. The narrator continues by explaining that because the mother gave birth to seven children within a five-year period, she was unable to support them when they were 
learning to walk. The scientists are then shown to be willing to compensate them for this lack of care. Humphrey stresses how 'culture can be so influential.'

The film emphasizes the point that quadrupedalism can be fixed through changes in the surrounding culture; accordingly, the scientists bring the family walking aids and other devices for learning to walk upright. The final sequences show family members learning how to walk with the help of a walking aid in their garden. At the same time, the narrator talks about 'hope.' The film stresses that human beings walk upright. This assumption certainly reinforces ableist presumptions about human bodies, and dismisses how disability studies have interrogated seemingly benevolent rehabilitation practices that support the cultural norm of walking (Oliver 1993). These sequences also show that for natural scientists the molding of cultural factors can be a way to shape a material body. The film connects the bodies of nonwhites with non-human species. At the same time, it understands able-bodied humanity to express the right direction of evolution as the talk about hope implies. Still, the film does not understand underdeveloped-appearing bodies to be unalterable. Rather, it understands that the cultural factors of particular locations indicate either development or underdevelopment and that it is possible to shape the bodies of the underdeveloped in a direction that brings those bodies closer to the locations that are associated with development. The notion of culture as either developed or underdeveloped has been part of racist cultural politics for a long time (Balibar 1991). As we have seen in this section, at the present historical moment the theory of human evolution has been clarified through the idea of underdeveloped culture and through comparing existing non-whites with non-human species. 
I want to underscore the way in which the film connects human quadrupedalism to another time. In the film, the past of human beings can be viewed from the location that is connected with underdevelopment. In the New York Times article, the writer needs a non-human animal for a description that concerns how human beings move in water. The writer assumes that human beings return to their past as quadrupeds when they swim. In 'The Family that Walks on All Fours,' quadrupedalism is distanced from existing human beings. Still, in both of these texts, quadrupedalism is a quality of existing human beings. The next section discusses how a fossilized animal named Tiktaalik, and existing fish, have been connected with human bodies.

\section{The discovery of Tiktaalik as 'our ancestor'}

In 2006, Neil Shubin, a paleontologist, published an article in the distinguished journal Nature. The article introduced a recent paleontological discovery: a fossilized animal named Tiktaalik. Almost immediately after Shubin had published the article, Tiktaalik became a public entity upon which various hopes and fears rested. A week after the publication in Nature, The Guardian deemed the discovery 'a missing link between fish and land animals'. The Guardian article cited the famous evolutionary biologist Richard Dawkins, who stated 'Our emergence on to the land is one of the more significant rites of passage in our evolutionary history, and Tiktaalik is an important link in the story'. A year later, Shubin published a popular scientific book entitled Your Inner Fish - The amazing discovery of our 375-million-year-old ancestor. In 2013, the BBC aired the documentary film 'Triumph of the Vertebrates.' On the film's website, it is possible to view only one clip online: 'Tiktaalik: First Steps.' The short clip introduces us to a species that swims in a sea. At the same time, when the creature clambers out of the water onto dry land, majestic music plays, and the voice of David Attenborough tells us that what we have just seen is 'one of the most spectacular 
events in evolutionary history' (David Attenborough's Rise of Animals). 'Our ancestor' has just taken its first steps on land. At the present time, Tiktaalik is also appearing in the cultural politics surrounding the debate on evolution vs. creationism. Web shops sell t-shirts exclaiming 'I'm proud to be a descendant of Tiktaalik Roseae (Café Press). Here, Tiktaalik symbolizes progressive ideas, and wearing the shirt distances you from those who want to be descendants of Adam and Eve. I will now turn to the question of how the exceptionality of humanity has, still, intertwined with the figure of Tiktaalik. Furthermore, this section suggests that the way in which Tiktaalik is connected with human bodies distances particular human beings from humanity.

According to Shubin (2008, 22), Tiktaalik was an animal species 'between fish and landliving animals.' Tiktaalik, as Shubin $(2008,23)$ puts it, 'broke down the distinction between these two different kinds of animals.' Shubin $(2008,23)$ emphasizes that although Tiktaalik had fins, it also had 'bones that correspond to the upper arm, the forearm, even parts of the wrist.' Shubin explains that Tiktaalik makes it possible to understand that different species are, in fact, versions of each other, and that human beings belong to the animal world through their bodies. The point that Tiktaalik had bones which 'correspond' to bones in the human skeleton is not however, the only reason for Shubin to claim that humans have a deep connection to non-human species. Shubin also underscores how the biosciences have demonstrated that old genetic connections exist between different species. Genes can often inform about where one comes from and who one is, and moreover, the knowledge of one's genetic past appears to arouse important feelings of belonging (M'charek 2005).

Shubin (2008) introduces an experiment that focused on a gene called Sonic hedgehog. He explains that this particular gene makes possible the shape of a hand that is characteristic of all limbed animals, that is, the thumb is different from the other digits. Thus, species with 
limbs also have the Sonic hedgehog gene. Shubin $(2008,58)$ explains how it is possible to demonstrate that 'all appendages, whether they are fins or limbs, are built by similar kinds of genes.' The notion that there are 'similar kinds of genes' among various species makes genes appear as hidden potentialities. For Shubin, the formulation of 'similar kinds of genes' implies that even though fish do not have hands, the potential for this exists in their genes (Ibid., 44-59).

The research team wanted to show that fish, as well, have a non-active Sonic hedgehog gene, meaning a sequence of DNA almost identical to an active gene - but not coding protein ${ }^{\mathrm{i}}$. They conducted an experiment that turned the gene on. The experiment showed that skeletal rods are reminiscent of the mammalian hand developed for skates. (Ibid., 54-59.)

According to Shubin, the outcome illustrates that the gene, which is passive in skates, is activated when a skate embryo is treated with mouse Sonic hedgehog protein. Shubin (2008, 54) refers to this experiment as a process that 'giv[es] sharks a hand.' That it was possible to 'gi[ve] sharks a hand' appears, according to Shubin (58), to suggest that 'the great evolutionary transformation' in which fins evolved into limbs was made possible through 'ancient genes.' While the Sonic hedgehog gene apparently enables humans to realize that they belong to the animal world, I would suggest that the way in which the activity of the Sonic hedgehog gene is connected with human bodies reinforces the idea that only a particular kind of body is species-typical of human being.

Although Shubin illuminates the notion of belonging to the animal world in a seemingly rational way, relying on his experimental results, he still makes clear his feelings towards beings that resemble himself: 
In retrospect, the moment when I first saw the wrist of a fish was as meaningful as the first time I unwrapped the fingers of the cadaver back in the human anatomy lab. Both times I was uncovering a deep connection between my humanity and another being. (Shubin 2008, 43)

Shubin states that during a human dissection at medical school it was not before he started examining the hand of a cadaver that he realized 'this had once been a living person' (29). Following this account, he eloquently explains how humanity and hands intertwine with each other. This story appears in a chapter where Shubin emphasizes how 'we are not separate from the rest of the living world' (43), and one cannot help but wonder how the point that the human hand is culturally loaded with ideas of ability and dexterity intertwines with the way that Tiktaalik, too, is recognized as 'our ancestor.' Here, the 'cultural politics of emotion,' as Ahmed (2004) would put it, define what bodies touch 'us,' what bodies are immediately recognized as being close to 'ours.' The way in which Shubin highlights capable bodies intertwines with the notion that the bodies of non-human species are inferior:

When we do push-ups, our hands lie flush against the ground, our elbows are bent, and we use our chest muscles to move up and down. Tiktaalik's body was capable of all of this. [...] Tiktaalik might be able to do a push-up, but it could never throw a baseball, play the piano, or walk on two legs. $(39,41)$

It is important to note that scientific practices involving modifying animals and creating mutant populations are Shubin's principal ways of arguing that humans are connected through their bodies 'to the rest of life.' Thus, 'working animals,' as Haraway $(2008,72)$ calls laboratory animals, are important agents - albeit far from equal to laboratory scientists - in 
the cultural processes that enable humans to belong to the animal world. When Haraway uses the term 'working animals,' she highlights the importance of laboratory animals and seeks to rethink the assumption of laboratory animals being simply victims. Drawing on Haraway's idea I suggest that fish that are born in laboratories are no less fish. In other words, when Shubin explains how a skate embryo was treated with a mammal's protein and this way its Sonic hedgehog gene was activated, he still does not assume that these new fish would be anything other than fish because for him the process 'giv[es] sharks a hand.' Still, how does he connect an active Sonic hedgehog gene with humanity?

In Shubin's work, the point that humans are genetically connected to fish is illustrated through the experiment that 'give[s] sharks a hand.' However, as Shubin points out, human beings as well have the potential to form appendages that resemble fins. Shubin explains this in the following way: 'If Sonic hedgehog hadn't turned on properly during the eight week of your own development, then you either have extra fingers or your pinky and thumb would look alike. Occasionally, when things go wrong with Sonic Hedgehog, the hand ends up looking like a broad paddle with as many as twelve fingers that all look alike' (53). Here, a disabled body intriguingly expresses the idea that humans are genetically connected to fish. Fish with 'hands,' together with human developmental disabilities, exemplify 'deep connections' between humans and fish.

I would suggest that Shubin's work makes it clear that the Sonic Hedgehog gene can appear either as passive or active both in human beings and fish. Skates who were born in the laboratories where Shubin's team conducted their research had an active Sonic Hedgehog gene. Human beings who are born with paddles have a passive Sonic Hedgehog gene. Thus even though Shubin's research actually undermines the connection between the active Sonic 
Hedgehog gene and humanity, the ways in which he highlights that bodies with hands invoke a deep bond make human beings with paddles to seem less human. Here we have seen how a particular evolutionary biological account that enables Tiktaalik to emerge as an ancestor of human beings eventually emphasizes that only a particular kind of body is species-typical of a human being. In the next section, I explore how human beings could belong to the animal world in a way that could contest able-bodied belonging.

\section{Contesting the species-typical body}

With reference to Shubin's exploration, Lynn Sherr $(2012,42)$ points out in her book SwimWhy we love the water: 'So why we don't talk about our connection to fish? How come we only acknowledged the great apes?' Sherr connects Shubin's findings with the idea of being able to swim illustrating that human beings have more abilities than non-human species. Sherr (2012) claims that she is investigating why people love the water, and she uses the history of swimming, her own experiences, and Shubin's research in this investigation. Sherr $(2012,43)$ quotes Shubin as he considers what is exceptional in humans: 'what's great about humans is that we can inhabit almost every environment, right? We're a species that is amazingly variable. ${ }^{\text {ii }}$ Sherr $(2012,43)$ interprets this to mean that 'fish swim because they have to; we do it by choice.' It is the potentiality of various abilities that is associated with humanity. Disability studies scholar Tobin Siebers $(2008,10,117)$ has called attention to the contradictions surrounding the dominant cultural understandings of able-bodiedness. He has claimed that although the idea of able-bodiedness involves an assumption of sameness, the able body appears to be a body that 'can be trained to do almost anything.' For Sherr, swimming appears to be an example of this kind of abled potentiality. Thus for readers, this story offers an experience of having more abilities than non-human species. Here, 'ablebodied 
belonging' frames the experience where one feels that one is connected to non-human species. Evolutionary biology is here popularized by using swimming when illustrating the point that humans belong to the animal world.

The way in which Sherr uses swimming in her text eventually hierarchizes species. The hierarchy is constructed according to a species' capacity for different forms of locomotion. However, the way in which the capacity for different forms of locomotion has been connected with able-bodied humanity interestingly contradicts the human quadrupedalism that emerges from the film 'The Family that Walks on All Fours.' While the film suggests that human beings move only in a particular way, human beings as 'amazingly variable' (Sherr 2012, 43) might emphasize how human beings could belong to the animal world in a way that could contest the species-typical body.

Furthermore, if swimming makes one realize that one is 'a quadruped again,' how might this realization change the way other forms of human quadrupedalism are valued? Might it be possible to connect swimming with quadrupedalism in a way that does not distinguish it from other forms of quadrupedalism and thus challenge the stubborn notion of bipedalism as the most developed form of human movement? In other words, if swimming is an exceptional ability of human beings, as Sherr suggests, then the connection between humanity and bipedalism could be contested. What about ways of swimming that are not understood as 'real' swimming? Flippers are often recommended for aquatic training because it is easier to propel oneself with them. Yet we are told that they should be used only temporarily. As many non-swimmers know (let alone all those who have taken swimming lessons), swimming, at least without flippers or other aids, can 'feel very unnatural.' The purpose of swimming lessons appears to be to conquer these feelings and to learn to travel in the water without aids 
that are not part of the species-typical body of a human being. But, could it be possible to use flippers as a way to emphasize one's connection to 'the rest of life,' and could this discredit the assumption that humans just naturally have more abilities than other species?

Alison Kafer $(2013,142)$ has suggested that feminist disability studies should consider the relationship between bodies and nature in a way that would enable this relationship to emerge 'through the lenses of loss and ambivalence.' In this respect, the approach that Kafer suggests might lead us to point out that even though human beings have descended from animals who lived in the water, for human beings it is not an environment that they could inhabit as easily as many other existing species. When human beings experience themselves as a species who lack the qualities of non-human species, their belonging to the animal world can make them less sure about their exceptionality.

\section{Conclusions}

The present article has investigated how evolutionary biological accounts enable a feeling of belonging to the animal world in a way that prioritizes able-bodied humanity. The article suggests that even though evolutionary biological accounts assume that the human body is able to emerge in various forms, they still distance particular bodies from humanity. The question framing my investigation is this: 'What are the cultural blocks that prevent evolutionary biological accounts from emerging without prioritizing able-bodied humanity?' Because human beings have turned to non-human animals when endeavoring to understand themselves, non-human species are inseparable from the culture in which they appear (e.g. Haraway 1989). In this respect, cultural mechanisms such as racism and ableism intertwine with understandings that ostensibly appear to be only about nature. In this article, we have 
seen how phenomena that scientists are fascinated by - quadrupedalism and the Sonic Hedgehog gene - and their understanding of them, invoke able-bodied belonging.

The article explored how two cultural mechanisms of belonging - able-bodied belonging and belonging to the animal world - intersect. My concept of 'able-bodied belonging' provides a way to analyze the various relationships between ableism and the forms of belonging. 'Ablebodied belonging' explores the question of what kind of human being appears in the mechanisms that enable the modes of belonging. The concept of 'able-bodied belonging' also leads to the question of what kind of assumptions about bodies frame various kinds of communities, including nation states and other imagined communities (cf. Anderson 2006) as well as countercultural movements and intimate groups. In this article, the community, clearly imagined, is seen as consisting of both human and non-human species, and, in the article's final section, I sketched out a blueprint for an alternative relationship between human beings and non-human animals. Indeed, belonging can make unexpected ends possible because when people belong to various communities they are affected by others. In this sense, belonging can change affective responses and hence make us think about evolution as well as our own and non-human species' bodies in a different way.

\section{References}

Ahmed, Sara. 2004. The Cultural Politics of Emotion. Edinburgh: Edinburgh UP.

Anderson, Benedict. 2006 [1983]. Imagined Communities. Reflections on the Origin and Spread of Nationalism. London: Verso.

Balibar, Etienne. 1991. Is There a "Neo-Racism”? In Race, Nation, Class. Ambiguous

Identities, ed. Etienne Balibar and Immanuel Wallerstein, 17-29. London: Verso.

Café Press. http://www.cafepress.co.uk. Accessed 07/01/2016. 
Campbell, Fiona Kumari. 2001. Inciting legal fictions: Disability's date with ontology and the ableist body of the law. Griffith Law Review 10 (1): 42-62.

Castañeda, Claudia. 2001. Developmentalism and the Child in Nineteenth-Century Science. Science as Culture 10 (3): 375-409. doi: 10.1080/09505430120074145

Chen, Mel. 2012. Animacies. Biopolitics, Racial Mattering, and Queer Affect. Durham: Duke UP.

David Attenborough's Rise of Animals: Triumph of the Vertebrates. http://www.bbc.co.uk/programmes/b03bgs18. Accessed 07/01/2016.

Futuyma, Douglas. 1998. Evolutionary Biology. Sunderland: Sinauer Associations.

Goulden, Murray. 2009. Boundary-work and the human-animal binary: Piltdown man, science and the media. Public Understanding of Science 18 (3): 275-291. doi: $10.1177 / 0963662507081239$.

Groce, Nora Ellen and Jonathan Marks. 2000. The Great Ape Project and Disability Rights: Ominous Undercurrents of Eugenics in Action. American Anthropologist 102 (4): 818-822. doi: 10.1525/aa.2000.102.4.818

Hall, Kim Q. 2012. "Not Much to Praise Such Seeking and Finding”: Evolutionary Psychology, the Biological Turn in the Humanities, and the Epistemology of Ignorance. Hypatia 27 (1): 28-49. doi: 10.1111/j.1527-2001.2011.01229.x

Haraway, Donna. 1989. Primate Visions. Gender, Race, and Nature in the World of Modern Science. New York: Routledge. Haraway, Donna. 1997.

Modest_Witness@Second_Millennium.FemaleMan_Meets_OncoMouse. London: Routledge. 
Haraway, Donna. 2008. When Species Meet. Minneapolis: University of Minnesota Press.

Hemmings, Clare. 2011. Why Stories Matter. The Political Grammar of Feminist Theory. Durham: Duke UP.

Jha, Alok. 2006. Moving on to the land. The Guardian.

http://www.theguardian.com/science/2006/apr/14/fossils.evolution. Accessed 07/01/2016.

Kafer, Alison. 2013. Feminist, Queer, Crip. Bloomington: Indiana University Press.

Katsoulis, Melissa. 2008. Best new summer reading of 2008. The Telegraph.

http://www.telegraph.co.uk/culture/books/bookreviews/3554457/Best-new-summer-

readingof-2008.html. Accessed 08/01/2015.

Martin, Emily. 1994. Flexible Bodies. Tracking Immunity in American Culture - from the Days of Polio to the Age of Aids. Boston: Beacon Press.

M'charek, Amade. 2005. The Human Genome Diversity Project. An Ethnography of Scientific Practice. Cambridge: Cambridge UP.

McRuer, Robert. 2006. Crip Theory: Cultural Signs of Queerness and Disability. New York: New York UP.

Oikkonen, Venla. 2013. Gender, Sexuality and Reproduction in Evolutionary Narratives.

London: Routledge.

Oikkonen, Venla. 2015. Mitochondrial Eve and the Affective Politics of Human Ancestry. Signs 40 (3): 747-772. doi: 10.1086/679527

Oliver, Mike. 1993. What's so wonderful about walking? Inaugural professional lecture 9 February 1993. http://disability-studies.leeds.ac.uk/files/library/Oliver-PROFLEC.pdf. 
Accessed 24/02/2015.

Sherr, Lynn. 2012. Swim: Why We Love the Water. New York: Public Affairs.

Shubin, Neil., Daeschler Edward and Farish Jenkins. 2006. The pectoral fin of Tiktaalik roseae and the origin of the tetrapod limb. Nature 440 (7085): 764-771. doi:

10.1038/nature04637

Shubin, Neil. 2008. Your Inner Fish-The amazing discovery of our 375-million-year-old ancestor. London: Penguin Books.

Siebers, Tobin. 2008. Disability Theory. Ann Arbor: University of Michigan Press.

Snyder, Sharon and David Mitchell. 2006. Cultural Locations of Disability. Chicago: The University of Chicago Press.

Summer Pond. 1979. New York Times (Aug 1, 1979, pg A22)

Taylor, Sunaura. 2012. Animals and Ableism.

Http://animalsanddisability.wordpress.com/2012/06/26/sds-presentation-animals-andableism/. Accessed 07/10/2014.

Terry, Jennifer. 2000. "Unnatural Acts" in Nature: The Scientific Fascination with Queer Animals. GLQ: A Journal of Lesbian and Gay Studies 6 (2): 151-193.

The Family that Walks on All Fours. Http://www.youtube.com/watch?v=Jwiz-yhLpT0. Accessed 24/9/2014.

Vaahtera, Elina and Emmi Vähäpassi. 2014. Vammaisuuden haluaminen ja kulttuuriset normit. In Muokattu elämä: teknotiede, sukupuoli ja materiaalisuus, ed. Sari Irni, Mianna Meskus and Venla Oikkonen, 233-263. Tampere: Vastapaino. 
Vehmas, Simo. 1999. Discriminative assumptions of utilitarian bioethics regarding individuals with intellectual disabilities. Disability \& Society 14 (1): 37-52. doi: $10.1080 / 09687599926361$

Warner, Michael. 2000. The Trouble with Normal: Sex, Politics, and the Ethics of Queer Life. Cambridge: Harward UP.

Yuval-Davis, Nira. 2011. The Politics of Belonging: Intersectional Contestations. Los Angeles: SAGE.

The idea that there are similar genes, albeit not turned on, is often explained through the term 'pseudogene.' Pseudogenes are sometimes called 'junk DNA.' Douglas Futuyma $(1998,104)$ refers to them as 'silent.' These 'silent' genes are 'nonfunctional genes related in sequence to functional genes (ibid., 325).'

ii However, this quotation from Shubin does not appear in Your Inner Fish - The amazing discovery of our 375-million-year-old ancestor (Shubin 2008). 